\title{
X-Raying Rainfall Pattern In Gombe State Over The Last Three
} Decades

\author{
${ }^{1}$ Yusuf Umar Ahmad, ${ }^{1}$ Yahaya, Ibrahim, \\ BSc in Geography (B.U.K), MSc in Geography (B .U. K)Department of Geography, Gombe State University, \\ Gombe State, (Nigeria) \\ B.Tech.in Geography (MAUTECH), MSc. in Geography with Specialization in Physical Geography \\ Climatology (BUK) \\ Department of Geography, Gombe State University, Gombe StateP. M. B 127,Gombe State, Nigeria
}

\begin{abstract}
In this work, monthly and daily rainfall records of 1977-2008 for Gombe station and that of Tumu which covers the period of 1965- 1997 as well as that of the other nine stations across the state were analyzed to describe changes in rainfall seasons, duration, number of rain days as well as the amounts of rainfall received per a given rainy season. It was observed from the data analyzed that there was delay in the starts and ends of rainy seasonin the northern parts of the study area of about 14 to 21 days. In the same vein, the numbers of rainy days as well as the amount of rainfall received in the two parts of the study area vary significantly when correlated. For example, rains lasted for about 36-59 days at Billiri station (lat 09 $51^{\prime} 50$ ") with 684.56mm mean annual rainfall in the southern Gombe, while Dukku(10 $\left.36^{\prime} 15^{\prime \prime}\right)$ in the northern part showed 17-55 rainy days with 650.27 mean annual within the same period. The average duration of the rainy season in the southern parts of the state (which is influenced by highland among other things) had 6-8 months, while that of the semi-Sahel area by the north was found to be only between 4-6 months. This also indicates that the duration of rainy season steadily decreases with increase in latitude. When the total rainfall was correlated with the number of rainfall days of all the stations using Matrix Laboratory (MATLAB) environment; the results of the correlation coefficient indicated that there was correlation between the rainfall amounts and the number of rainfall days across all the stations in the study area. The correlation coefficients even though with varying degrees of freedom (Table 9 i.e. n-1) are as follows: Gombe 0.1506; Billiri 0.2559; Kumo 0.7053; Talasse 0.0372; Kaltungo 0.6189; Dukku 0.5122; Bajoga 0.6929; Nafada 0.3549; Deba 0.5281 and Tumu 0.1293. The results of the Student t-test is such that the Student's t- test of the five stations out of the ten did not show significant relationships at $1 \%$ and $5 \%$ levels of confidence. These stations are Billiri,Deba, Gombe, Nafada, Talasse and Tumu. On the other hand, the remaining stations i.e. Bajoga, Dukku, Kaltungo and Kumo did show relationships. Hence, the study confirms that rainfall amounts vary over space and time.
\end{abstract}

Keywords: Rainfall, Pattern, Gombe Distribution and Variability

\section{INTRODUCTION}

Rainfall being the most important source of water supply controlling element in agriculture in Nigeria. The amount received, duration and distribution determine the type of agricultural activities that could be carried out in a particular area. The importance of rainfall to human existence on earth cannot be overemphasized. For plants and animals which are the most substantial sources of human food; depend largely upon climate for their survival. That is to say, climate determines the type of crop to be grown in a particular place, the food people eat, type of cloth, health, architectural design among other things.Studies have shown that world climates are not static; just like other natural geographical phenomena; rather they vary spatially and temporally. Similarly, climate-change is considered to be an environmental, social and economic challenge on the global scale. The most devastating adverse impacts of "climate change" in Nigeria and other sub-tropical countries include frequent drought events which resulted to increased environmental damage, crop failures due to late on-set and early cessation of rainfall regimes. These gradually lead to increased biodiversity loss and change in livelihood styles among other things.Furthermore, (Ariyo et al, 2004 cited in Olson and Lindsay, 2009) demonstrated that climate change may result in loss of plant species. In the same vein (Ojo, 1987 cited in Fasona and Omosojola, 2005) opined that these climatic changes are driven by combination of both natural and anthropogenic causes. Until recently, man's activities on climate variation were perceived as negligible, and so climate was generally taken for granted, and there was little thought that the climate could be a problem with severe impacts.

Today, because of climate and environmental-change effects on the human existence, the connection between environmental changes and human security become so strong. In addition, the debate on climatic change and variation as it concentrates more likely on global and regional futuristic occurrences which may be triggered off 
by the climate anomalies of the past and present. Much as this is valid, the vulnerable and (likely) adjustment or coping mechanism of people to the vagaries of climate may best be understood at micro and macro levels, hence the struggles for diminishing resources has increased as a result of climate variability.Obot et al (2010) emphasized that climate change and rainfall variability in particular seems to be the foremost global challenge facing humanity at the moment, even though it seems that not all places on the globe are affected. One of the indicators of climate change is rainfall! Therefore rainfall is a climate parameter that affects every facet of the ecological system, flora and fauna inclusive. Hence, the study of rainfall is important and cannot be overemphasized. Rainfall is generally believed to be one of the critical factors or elements of climate that controls the rhythm of life and livelihood of people in the north-eastern part of Nigeria to a very large extent. This is because of the fact that rainfall is the major source of moisture for crops and water for animals which are the major sources of food for man in the region.

Agriculture (both crop cultivation and animal production) in Gombe State where over $80 \%$ of the farmers are engaged in rain fed cultivation (SEEDS, 2006; GSADP, 2009), is to a large extent conditioned by the patterns of rainfall in terms of amount, duration, intensity and distribution. The upper Sudan and the Sahelian zone receive less rain which makes it critical to crop cultivation and production. That is why climate change is viewed as one of the greatest challenges of modern society as discussed at the United Nations' International Conferences on Climate Change Copenhagen, December, 2009; November, 2010 Cancun Mexico; November 2011 Durban South Africa; Doha 2012; Warsaw Poland November 2013 respectively. In view of this therefore, the risks of climate change and rainfall variability in particular has adverse impacts on the socioeconomic wellbeing of the people in the study area. This is very fundamental due to the fact that more than $80 \%$ of the populace is believed to have taken part in either crop cultivation or animal production or both.

\section{STUDY AREA}

Gombe state (the Jewel in the Savanna) is located within the latitudes $9^{\circ} 30^{\prime}$ and $12^{\circ} 30^{\prime} \mathrm{N}$ and longitudes $8^{\circ} 45^{\prime}$ and $11^{\circ} 45^{\prime} \mathrm{E}$ on the sub -Sudan savanna region of the country at the north east of river Benue and east of Yankari Game Reserve. It shares borders with Bauchi state to the west, Adamawa state to the southeast, Taraba state by the southwest, Borno state to the east and Yobe states by the northeast. The state covers the total area of about 20,265 sq km. The approximate altitudes of Gombe ranges from 400-500m above mean sea level, (Fieldwork, 2010). The topography is mainly mountainous, undulating and hilly in the central and southern parts and open plains in the northern and northeastern parts of the state.

\subsection{Weather and Climate}

Nigeria often comes under the influence of two different air masses, namely north easterlies and south easterlies. These two air masses determine the weather conditions of the county, which gives rise to distinct seasons of the year. The north easterlies air masses that bring about harmattan-dust and dryness start usually by November to midst February. While the south easterlies air originated from the ocean which makes them moist warm and heavy (due to their source region). These air masses are associated with rainfall in the country. The two air masses meet at a point called inter-tropical discontinuity (ITD). It is the movement of ITD that causes variations in the weather conditions of the country.

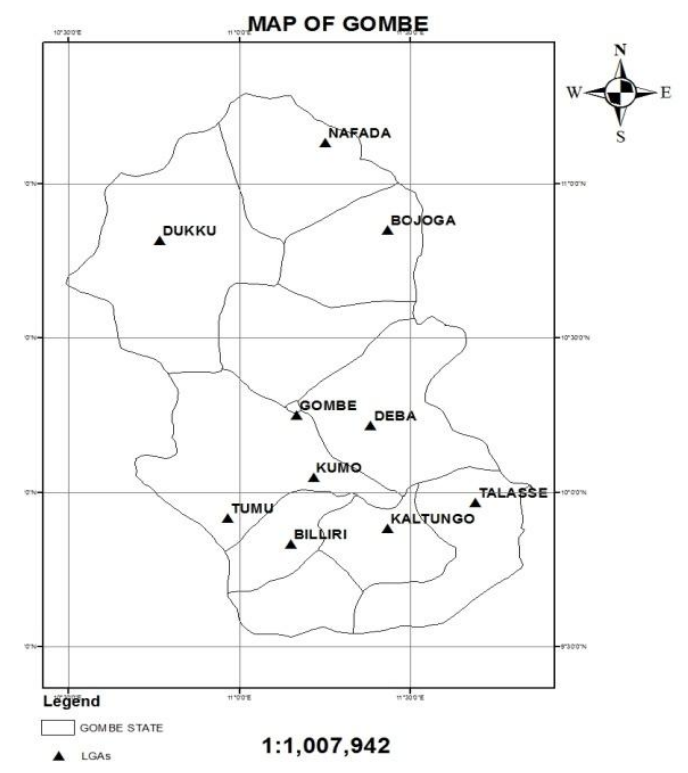


Figure 1: Gombe State Showing Locations of Meteorological Stations (Study area)

Gombe state, being located geographically within the sub-Sudan climatic zone, experiences the influence of these air masses from October to March and the influence of the south western air-masses from April to September. It receives an average precipitation between 900-1,000mm in 7 months per year (Salisu, 2000 cited in Hocking, 1979).There are monthly and daily rainfall variations all over the state. Thus annual rainfall could be as low as $850 \mathrm{~mm}$ as recorded in 1970 and 1989 or as high as $1200 \mathrm{~mm}$ as in 1953 (Nigerian Metrological Agency; in cited Salisu, 2000). The rainfall is concentrated between April/May to October with a single maximum in August or September. The dry season covers November to early March and April, which are usually the hottest months. However, heavy falls at over $76 \mathrm{~mm}$ per hour was recorded (Udo, 1970). However, the mean rainfall of $86.4 \mathrm{~mm}$ and $80.61 \mathrm{~mm}$ were recorded in 1997 and 2006 respectively.

The mean maximum monthly temperature of $37^{\circ} \mathrm{C}$ was recorded in April and March, while the minimum monthly temperature was about $21^{\circ} \mathrm{C}$ around December and early February which is considered as tropical wet and dry type coded Aw according to Koppen's classification system. The mean temperatures of $32.6{ }^{\circ} \mathrm{C}$ and 33.3 ${ }^{\circ} \mathrm{C}$ were recorded in 1997 and 2006 respectively.

\section{MATERIALS AND METHOD}

Secondary sources of data were considered in this paper. This consists of rainfall data for the ten meteorological stations across Gombe state sourced from the archive of the Gombe State Agricultural Development Project (GSADP). In the same vein, relevant information from library search, academic journals, internet, etc were used. Subsequently the data was transformed and analyzed using both descriptive and inferential statistics.

\subsection{Data Acquisition}

The rainfall data for this research was obtained from the Gombe State Agricultural Development Project (GSADP) office Gombe in collaboration with the Nigerian Meteorological Agency (NIMET). This collaboration took place in the recent years (i.e. around the year 2000) when NIMET took over the responsibility of maintaining and keeping climatic data of the GSADP meteorological stations across the state. Daily and monthly rainfall records of the ten meteorological stations for the period of thirty-one years (i.e. from 1978 to 2008) were used. These stations are located far- apart considering the geographical extent of Gombe State. Table 1show the distance and direction of each of the stations with respect to the state capital which was considered as reference point for this purpose.

Table1: Approximate Distances and Directions of the Meteorological Stations with Respect to Gombe Town.

\begin{tabular}{|c|c|c|c|c|}
\hline $\mathbf{S} / \mathbf{N}$ & Station & $\begin{array}{cc}\text { Distance } & (\mathrm{Km}) \text { from } \\
\text { Gombe Town } & \end{array}$ & $\begin{array}{c}\text { Direction with } \\
\text { Respect to Gombe } \\
\text { Town }\end{array}$ & $\begin{array}{c}\text { Period of Data Coverage } \\
\text { Available }\end{array}$ \\
\hline 1 & Bajoga & 86 & North & 17 \\
\hline 2 & Billiri & 60 & South & 22 \\
\hline 3 & Dukku & 84 & Northwest & 18 \\
\hline 4 & Deba & 40 & East & 10 \\
\hline 5 & Kaltungo & 73 & South & 17 \\
\hline 6 & Kumo & 41 & South & 20 \\
\hline 7 & Nafada & 122 & Extreme North & 14 \\
\hline 8 & Talasse & 91 & Southeast & 21 \\
\hline 9 & Tumu & 34 & South & 30 \\
\hline 10 & Gombe & 0 & - & 31 \\
\hline \multicolumn{4}{|c|}{ Source: Fieldwork, 2010.} & \\
\hline
\end{tabular}

The stations in Table1 possess the reliable and readily available climatic data for the entire state. These stations were considered in order to ensure adequate sample areas which could represent the entire study area (Figure 1.1), although, most of these stations have not been functioning since 1999. Most of the records as for the functional stations have commenced since late 1970s. This enabled the researcher to collect rainfall data to meet the minimum requirements of the World Meteorological Organization (WMO) in making inference concerning the climate of a particular place.

\subsection{Data Transformation}

The daily and monthly rainfall records of the ten meteorological stations across the state were summed up. Also the total numbers of rainy days as well as the rainfall amounts for individual stations were computed.In 
addition to that the rainfall mean, the standard deviation and the coefficient of variation were also computed using Matrix Laboratory (MATLAB) environment. The MATLAB is computer software used by scientists and engineers which is designed to solve simple and complex statistical and mathematical problems. The annual rainfall values for four stations (i.e. Dukku and Nafada in the north; and Billiri and Tumu from the south) covering the period of 1981 to 1998 were equally analyzed using the standardized anomalies which shows departures at a glance. This time frame (1981 to 1998) was used considering the fact that each of these stations has rainfall records covering the said period of time.

\subsection{Data Analysis}

The daily rainfall values obtained were summed up and then the average monthly totals from January to December of each year for each station covering the specified period of time was also computed using the standardized Anomaly Index (SAI) in order to determine the extent of the variability which would also enable us to observe the mean departure at a glance. The SAI was computed by subtracting the actual rainfall amounts of any given station from the mean rainfall value and then dividing them by the standard deviation. In addition, this index is simple, therefore widely applied to rainfall and later extended to temperature variability for its capability of giving useful and synthetic climatic indications for large territories expressed as a single value.

After that, descriptive statistics of the long term daily, monthly and annual rainfall characteristics of each station was computed. This was done with a view to facilitate the understanding of the temporal and spatial variations of rainfall within the study area. Hence variability indices were computed as coefficient of variability. The latter is the standard deviation divided by the mean. The resulting fraction was then converted to percentage. Computer packages especially SPSS, MATLAB and excel were used in the data analysis. Similarly, the duration, intensity and distribution of rainfall within a particular rainy season were been determined.

The correlation coefficients between the number of rainfall days and the rainfall amount were determined using correlation coefficient index. This index determines the degree of relationship between the two variables. The values for r-calculated was then converted to Student t-test in order to test for relationship.

\section{RESULTS AND DISCUSSION}

The annual rainfall amounts as well as the total number of rainy days in all the stations under investigation were computed and also rainfall variations within the given years vis-à-vis the lengths of rainy seasons were determined. The starts and ends of rainy season were then correlated with latitudinal locations of all the stations in question.In addition, the values for the correlation (r) subjected to Student t-test in order to test the relationships both at $1 \%$ and $5 \%$ levels of confidence. Finally, the total rainfall amounts, the five-year running means as well as the long-term monthly rainfall values of all the stations were presented on line and bar graphs respectively.

\subsection{The Onset and Cessation of Rains}

Kowal and Knabe (1972) defined the starts of rains as the first ten days in the season in which the amount of rainfall received is equal or greater than $25 \mathrm{~mm}$ but with two subsequent decades of precipitation greater than 0.5 evapotranspiration. While the end of rains is defined as the last ten-day period of rainy season with at least $12.5 \mathrm{~mm}$.Interestingly, there is variation in the onset of rains based on the data obtained from the ten meteorological stations across the state. For example, in stations such as Talasse, Kumo and Gombe; rains begun in the second week of March. These stations were considered to have received rains early, while in the other stations such as Dukku and Nafada rains begun mostly around third week of April or second week of May as the case maybe.

Generally, one can say that there is little variation in the starts and ends of rainfall considering the fact that rains mostly start around April/May except in few cases. For instance, at the Gombe stationrain starts around second or third week of March only within nine years out thirty-two (from 1977-2008). In other words, rains start mostly around April/May and end by October/November. This portrays the delay in the starts and ends of rains as witnessed in the sudano-sahelian sub-region of the state. This is contrary to what is obtained in the southern parts of the state which is mostly influenced by the Guinea Savanna.However, in very rare situations, rains begin around the first week of July or June as was recorded at Kaltungo station in 1987 and 1989. There was also a peculiar situation when rains started in the first week of August in 1980 as recorded in some stations. Similarly, at the Billiri station, rains start mostly around the second week of May. However, there are few instances when it started in the third week of March and the second week of April.

If one considers the situation in the Dukku station -which is located at the extreme northwestern parts of the study area very close to Darazo in Bauchi state; one discovers that rains started in the first week of June in 1990 and 1993, although that was unusual. But the usual period for the start of rains as revealed by the Dukku station happened to be the third week of April to the second week of May. On the other hand, rains are terminated around the second week of October; it was in rare situations whereby rains ceased in the second week of August 
in the year 1991 with only 32 rainy days. That year was considered to be a drought year in which rains ended earlier than usual.It is also interesting to note that the feature regarding the onset and cessation of rains is closely related to the latitudinal locations of these stations as shown in Table 2. In other words, Billiri, Kaltungo, Balanga, Kumo, Talasse areas are affected by the influence of Guinea Savanna of the Adamawa highlands than the other areas in the northern parts of Gombe such as Nafada, Dukku, Bajoga, which are considerably located within the Sudan Savanna zone bordering Yobe and parts of Bauchi (Darazo) states.

Furthermore, from the data available for the rainfall season of Gombe in 1977 the rain lasted for only 35 days and spread within five months amounting to $603.7 \mathrm{~mm}$. Similarly, in the year 2007, the rain lasted for only six months with total rain days of 51 and in the year 1987 the total amount of rainfall was $527.5 \mathrm{~mm}$ spread over 47 days. These years were considered to have received small amounts of rainfall when compared with what was received in the years of $1978(1080 \mathrm{~mm}), 1980(968.7 \mathrm{~mm})$ and $1992(1135.7 \mathrm{~mm})$.

\subsection{Length of Rainy Season}

The length of rainfall seasons as well as its distribution is as important as the total amount of rainfall received within a particular rainy season. As stated earlier that the length of rainy season in the study area and indeed everywhere is controlled largely by latitude. For example, in the study area places/stations closer to the Adamawa highlands such as Billiri, Kaltungo, etc exhibit longer periods of rainy seasons than those in the northeastern and northwestern bordering Bauchi and Yobe states such as Dukku, and Nafada. This factor among other things could be the reason why rainfall lasts for about 36-59 days at Billiri station; 27-50 days at Kumo; 34-52 days and 37-62 days at Talasse and Tumu stations respectively, all in the southern Gombe. While the number of rainfall days decline as one approach northwards. For example, the minimum and maximum numbers of rainy days 17-55 were recorded at Dukku station; 12-49 days at Bajoga station and also 17-51 days were recorded at the Nafada stations; all the northern part of the study area.

\subsection{Mean Annual Rainfall}

Table 5 illustrates the effect on mean annual rainfall of the stations. Table 4 also, summarizescorrelation coefficient values between total rainfall and rainy days the mean annual rainfall amounts for the entire stations. The situation here is not entirely different from what has been pertaining to the onset and cessation as well as the length of rainy season. The total annual rainfall was found to have exhibited an inverse relationship with latitude. In other words, as one progresses to the south from the north, one experiences an increase in the total annual amount of rainfall. This explains the fact that there exists a relationship between the onset and cessation in one side; and on the other side the length of rainy season. Note that the rainfall data of Tumu and Dukku stations for the year 1967 and 1998 respectively could not be treced in the archive of the GSADP Gombe. However, the story is differently in the case of Deba and Gombe stations. These two stations have recorded the range of rain days between 35-78 and 34-63 days respectively.

The average duration of the rainy season in the southern parts of the state (which is influenced by highland) had 6-8 months, while that of the Sahel savanna was found to be only between 4-6 months. This indicates that the duration of rainy season steadily decreases with increase in latitude. See Table 3.

Table2: Descriptive Statistics of Rainfall for the Stations Under investigation

\begin{tabular}{|l|l|l|l|l|l|}
\hline S/N & Station & Latitude & $\begin{array}{l}\text { Mean Annual } \\
\text { Rainfall }(\mathbf{m m})\end{array}$ & $\begin{array}{l}\text { Standard } \\
\text { Deviation }\end{array}$ & Coeff. of Var. \\
\hline 1 & Deba & $10^{\circ} 12^{\prime} 40^{\prime \prime}$ & 684.56 & 327.9187 & 47.90 \\
\hline 2 & Dukku & $10^{\circ} 36^{\prime} 15^{\prime \prime}$ & 650.27 & 328.2320 & 50.47 \\
\hline 3 & Gombe & $10^{\circ} 17^{\prime} 35^{\prime \prime}$ & 914.13 & 235.7669 & 25.77 \\
\hline 4 & Kaltungo & $09^{\circ} 48^{\prime} 54^{\prime \prime}$ & 1104.82 & 458.4204 & 41.49 \\
\hline 5 & Billiri & $09^{\circ} 51^{\prime} 50^{\prime \prime}$ & 819.10 & 462.7892 & 56.50 \\
\hline 6 & Nafada & $11^{\circ} 05^{\prime} 45^{\prime \prime}$ & 601.40 & 323.7619 & 53.83 \\
\hline 7 & Bajoga & $10^{\circ} 5116^{\prime \prime}$ & 671.43 & 366.7150 & 54.62 \\
\hline 8 & Kumo & $10^{\circ} 02^{\prime} 45^{\prime \prime}$ & 970.55 & 352.7894 & 36.34 \\
\hline 9 & Tumu & $10^{\circ} 00^{\prime} 14^{\prime \prime}$ & 718.47 & 394.2426 & 54.87 \\
\hline 10 & Talasse & $09^{\circ} 57^{\prime} 57^{\prime \prime}$ & 970.55 & 625.3082 & 64.43 \\
\hline
\end{tabular}

Table 3, clearly indicates that there is inverse relationship between latitudes and the mean annual rainfall figures across all the stations in question. In other words, as latitude increases, the mean annual rainfall decreases and vise-versa. For example, are Billiri, Kaltungo and Tumu with the following latitudes and mean annual rainfall amounts: $09^{\circ} 5150^{\prime \prime}(819.10 \mathrm{~mm})$; $09^{\circ} 48^{\prime} 54^{\prime \prime}(1104.82 \mathrm{~mm})$; and $10^{\circ} 00^{\prime} 14^{\prime \prime}(718.47 \mathrm{~mm})$ respectively. Also, if one considers other stations in the northern parts of the state such as Dukku $10^{\circ} 36^{\prime} 15^{\prime \prime}$ $(650.27 \mathrm{~mm})$; Nafada $11^{\circ} 05^{\prime} 45^{\prime \prime}(601.40 \mathrm{~mm})$ and Bajoga $10^{\circ} 51^{\prime} 16^{\prime \prime}(671.43 \mathrm{~mm})$; one would clearly notice that as latitude increases mean annual rainfall decreases.From the above explanation regarding these four stations, one would say that there is a decline in the mean annual amount of rainfall as one approaches northern parts of the study area from the south ranging between $433.39 \mathrm{~mm}$ and $270.28 \mathrm{~mm}$.For instance, the years 1977, 1980, 
$1981,1983,1984,1986,1987,1988,1996,1990,1992,1993,1994$ and 1996 were generally found to be drier than other years with low rainfall amounts ranging between $300-750 \mathrm{~mm}$ per season. The mostly affected stations include Billiri, BalangaBajogaDukku, Deba, and Tumu to some extent. On the other hand, the years 1985, 1988, 1989, 1991, 1992, 1995 and 1997 to 2008 were found to be wetter as indicated in the record from most stations in the study area, more especially stations like Billiri, Kaltungo, Deba and Gombe stations due to their ecological linkages.

\subsection{Seasonal and Monthly Variability of Rainfall}

It is evident from the above discussions that the length of rainy season as well as the amount of rainfall received all over the stations across the study area varies from one season to another. For the purpose of this research, the rainfall data was used in order to identify wetter and drier periods within a given station across the study area based on the amount of rainfall received.Five to six months in the study area were found to be completely wet. That is from the wet season May to October, taking about a half of the year. The dry or barren months were from November to April. Any month with less than $25 \mathrm{~mm}$ of rains was considered to be critically dry. It was also observed that more than $60 \%$ of the total rains received in a particular rainy season were concentrated in August and September. These two months

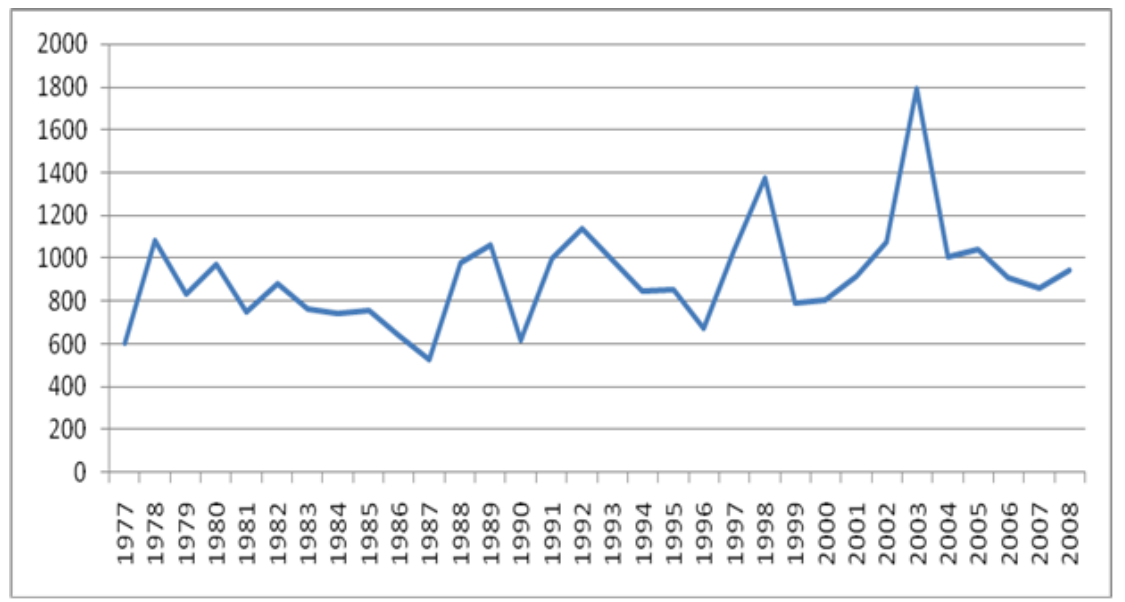

Fig. 1a Gombe Station

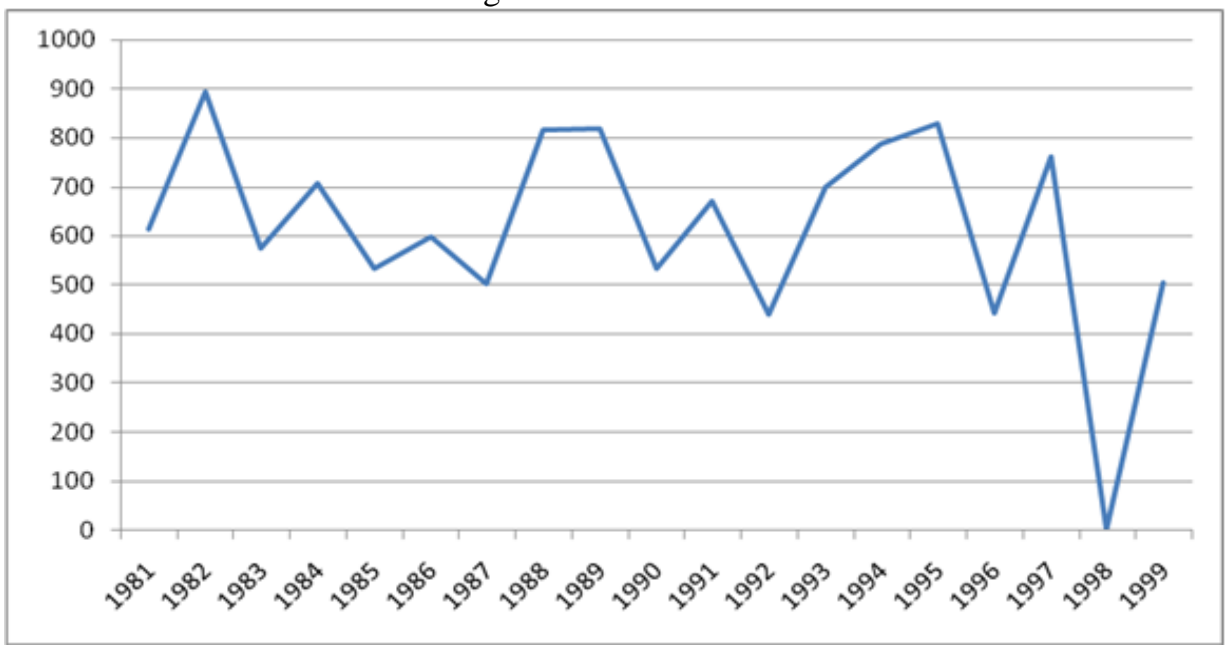

Fig. 1b Dukku Station

were indeed regarded as the wettest months in any given rainy season, as thus they are associated with very intense rains.

\subsection{Relationship between Total Number of Rain Days and Rainfall Amount}

It was hypothesized that there is a relationship between total number of rain days and the total amounts of rainfall received in all the stations within the study area. 
The total rainfall values were correlated with the number of rainfall days in all the stations using Matrix Laboratory (MATLAB) environment; the result of the correlation coefficient indicated that there is correlation between the two variables in all cases. The correlation coefficients are as follow: Gombe 0.1506; Billiri 0.2559; Kumo 0.7053; Talasse 0.0372; Kaltungo 0.6189; Dukku 0.5122; Bajoga 0.6929; Nafada 0.3549; Deba 0.5281 and Tumu 0.1293. (See details in Table 4 below).

Table 3: Correlation Coefficient Values between Total Rainfall and Rainy Days and their Student's t.

\begin{tabular}{|c|l|c|c|c|c|c|}
\hline S/N & \multicolumn{1}{|c|}{ Station } & r-cal & $\mathbf{t}$ & $\mathbf{0 . 0 1 \%}$ & $\mathbf{0 . 0 5 \%}$ \\
\hline 1 & Bajoga & 0.6929 & 1.7966 & & 3.25 & 2.262 \\
\hline 2 & Billiri & 0.2559 & 9.9082 & & 3.25 & 2.262 \\
\hline 3 & Deba & 0.5281 & 1.355 & & 3.25 & 2.262 \\
\hline 4 & Dukku & 0.5122 & 1.3131 & & 3.25 & 2.262 \\
\hline 5 & Gombe & 0.1506 & 3.8142 & & 3.25 & 2.262 \\
\hline 6 & Kaltungo & 0.6189 & 1.5966 & & 3.25 & 2.262 \\
\hline 7 & Kumo & 0.7053 & 1.8304 & & 3.25 & 2.262 \\
\hline 8 & Nafada & 0.3549 & 9.0354 & & 3.25 & 2.262 \\
\hline 9 & Talasse & 0.0372 & 9.4115 & & 3.25 & 2.262 \\
\hline 10 & Tumu & 0.1293 & 2.8717 & & 3.25 & 2.262 \\
\hline
\end{tabular}

Source Field work, 2010

From the Table 4, the values for $\mathrm{r}$-calculated and $\mathrm{r}$-tabulated were compared both at $5 \%$ and $1 \%$. The result is such that there is significant difference at Bajoga, Kaltungo and Kumo stations. At 5\%, Billiri, Deba, Gombe, Nafada, Talasse and Tumu did not show any significant difference. But 1\%, all stations did not exhibit significant difference except for Bajoga, Kaltungo, Kumo and Nafada. Therefore, four out of the ten stations did show significant difference both at 0.05 and 0.01 levels of confidence.

Table 4: Mean Rainfall Amounts Received and Periods across the Stations

\begin{tabular}{|c|l|c|c|c|}
\hline S/N & \multicolumn{1}{|c|}{ Station } & Period (Years) & & Rainfall Mean (mm) \\
& & & & \\
\hline 1 & Gombe & $1977-2008$ & & 914.13 \\
\hline 2 & Tumu & $1964-1997$ & & 807.75 \\
\hline 3 & Billiri & $1977-1999$ & & 819.1 \\
\hline 4 & Nafada & $1983-1995$ & & 601.4 \\
\hline 5 & Dukku & $1981-1999$ & & 650.27 \\
\hline 6 & Bajoga & $1981-1998$ & & 671.43 \\
\hline 7 & Deba & $1980-1990$ & & 684.56 \\
\hline 8 & Kaltungo & $1980-1999$ & & 1104.82 \\
\hline 9 & Kumo & $1977-1996$ & & 970.55 \\
\hline 10 & Talasse & $1977-1996$ & & 970.55 \\
\hline
\end{tabular}

Table 5 reveals that the mean rainfall amounts received at Kaltungo, Kumo, Talasse and Billiri which ranged from $807.75-1104.82 \mathrm{~mm}$ (all in the southern part) was higher than what was obtained at Bajoga, Dukku and Nafada (in the north) with the range of 601.4-671.43mm.

\subsection{Summary}

The research was able to find out that there exist differences in the quantity of rainfall received between the north and the southern parts of Gombe state based on the data collected from the ten meteorological stations across the state. The wet years were easily identified by the early onset and even distribution as well as the amounts of rainfall received within a given rainy season. The data also shows that rains mostly begin in the second week of March or early April in most stations and then ends around the first week of October to the third week of November. But some meteorological stations receive rains around the second week of May, even though there are few unusual situations whereby rains begun in the first week of June in 1990 and 1993 at Dukku station. Hence the study reveals that the average duration of rainy season in the southern parts of the study area is between 6-8 months, while that of the northern parts was found to be between 4-6 months. This indicates that the duration of rainy season steadily decreases with increase in latitude. For example, Billiri station $\left(09^{\circ} 51^{\prime} 50^{\prime \prime}\right)$ had received the mean annual of rainfall of about $819.10 \mathrm{~mm}$; Kumo $\left(10^{\circ} 02^{\prime} 45^{\prime \prime}\right)$ had $970.55 \mathrm{~mm}$ of rains, both in the southern part of Gombe. While Nafada and Dukku $\left(10^{\circ} 36^{\prime} 15^{\prime \prime}\right)$ and $\left(11^{\circ} 05^{\prime} 45^{\prime \prime}\right)$ stations both in the south had received the mean annual rainfall of $601.40 \mathrm{~mm}$ and $650.27 \mathrm{~mm}$ respectively within the period of 1977 to 1999 . The r-calculated values were converted to Student t-test. The result is such that five out of the ten stations did show relationship between rainfall amounts and the number of rainy days. The stations 
are: Gombe, Nafada, Talasse and Tumu both at 0.05 and 0.01 levels of confidence. On the other hand, the remaining five stations i.e. Bajoga, Dukku, Kaltungo and Kumo did not exhibit any relationship both at 5\% and $1 \%$. In view of that therefore, the starts and the ends of rainy seasons as well as the amounts and distribution of rain days determine e the effectiveness of that particular rainy season which in turns determine the success or failure of crops in a given farming season. Finally, the study stresses the fact that insufficiencies of rainfall, uneven distribution, delay in the onset, among other things result in crop failure, shortages and famines in study area especially around 1980 s when food production declined by about $20 \%$.

\subsection{Conclusion}

The total amount of rainfall across the state for more than thirty years period was assessed. The study revealed that there is a slight variations in the starts and ends of rains in all the ten meteorological stations investigated, more importantly the variations in the amounts of rainfall received between areas and between the north and south of the study area have been established. That is to say that rainfall amount decreases northwards. The factors leading to that include: latitude, nature of the soil, vegetation cover, wind characteristics, continentality and topography among other things.It was also observed that agricultural activities were more promising all things being equal (i.e. soil type and condition, labour) in the southern parts than the northern parts due to the differences in terms of the amounts and the lengths of rainy season that exist between them.Finally, the results of the analysis indicates that high moisture crops such as maize and rice could be cultivated successfully in the southern parts of the state, where the annual rainfall values range between $603.7 \mathrm{~mm}$ to $1791.00 \mathrm{~mm}$. While in the northern parts (where the annual rainfall values ranges between $325 \mathrm{~mm}$ to $848.30 \mathrm{~mm}$ ) such crops could hardly survive under rain-fed conditions. Instead, alternative crops which do not have high moisture requirements such as millet, sorghum, groundnuts, cassava, etc should be encouraged.

\section{RECOMMENDATIONS}

i. Thereare needs to further synthesize farmers on the importance of early planting exercise, drought and pest resistant species especially in the northern parts of the state.

ii. There is also need for the government and other stakeholders to strengthen institution studying climate issues in the state with the view to have access to up-to date climatic data.

iii. To stress on the weeds control, since they accelerate water loss Via transpiration at the expense of crops control with mearge amount of rainfall received in northern parts of Gombe state.

iv. There is need for the establishment of climate commission at state and local government levels so as to take case of the meteorological stations.

\section{REFEREENCES}

[1] Adebayo, A.A. (2010): Climate Resource and Resistance to Agriculture. In An Inaugural Lecture $8^{\text {th }}$ Series of Federal University of Technology, Yola ABTI Printing Press Yola Nigeria.

[2] Adefolula, D.O. (1986): Rainfall Trends in Nigeria: The Theoretical Climatology. In: SprnggerlinkVerlag, Vol. 37, No. 4, pp.205-219.

[3] Agboola, S.A (1979): An Agricultural Atlas of Nigeria Oxford University Press.

[4] Ayoade, J. O. (2004): Introduction to Climatology for the Tropics, Spectrum Books Limited Ibadan Nigeria. Page 151-170.

[5] Ayoade, J. O. (2008): Techniques in Climatology, Stirling-Horden Publishers Ltd. Gaaf Building Oyo Road, Origun Off University of Ibadan, Oyo State, Nigeria.

[6] Buba, L.F (2000): Drought Occurrences and the Utilization of Rainfall for Agriculture in Northern Nigeria In: Issues in Land Administration and Development in Northern Nigeria, Department of Geography Bayero University, Kano.

[7] Buba, L.F (2009): Rainfall Variability over Northern Nigeria. Being Ph. D. Research Progress Report Seminar Presentation in the Department of Geography Bayero University, Kano.

[8] Ekemezie, E.A. (1992): Analysis and Characterization of Rainfall in Nigeria. M.Sc. Thesis Submitted to the Department of Geography, Ahmadu Bello University, Zaria (Unpublished).

[9] Farouk, A.A. (2006): Effect of Rainfall Variability on Water Level of Bagauda Lake, Kano. M.Sc. Thesis Submitted to the Department of Geography, Ahmadu Bello University, Zaria (Unpublished).

[10] Gombe State Fadama Development Office (2006): Natural Resources Baseline Survey Report. Interserve Associates Consulting Engineering, Gombe, Gombe State.

[11] Hess TM, Stephens W, Maryah UM (1995): Rainfall Trends in Northeast Arid zone of Nigeria (19611990). AgricFor Metro, J Phys., 6:7-17, browsed on www.journalsofforestmeteorology.com

[12] Ishaku, H. T. andMajid, R. F. (2010): X-Raying Rainfall Pattern and Variability In Northeastern Nigeria: Impacts on Access to Water Supply. Department of Urban and Regional Development; University of Technology, Malaysia.Retrieved on the internet on the $20^{\text {th }}$ February, 2011. 
[13] Kowal, J.M. andKnabe, D.T. (1972): Agricultural Ecology of West the African Savanna. QUP, London.

[14] Obot, et al (2010): Evaluation of Rainfall Trends in Nigeria for Over Thirty Years (1978-2007), browsed from www.academicjournals.org

[15] Odjugo, A.O. (2005): An Analysis of Rainfall and Its Implication in Nigeria. In: Global Journal of Environmental Sciences. Vol. 4, No. 2, pp.139-145.

[16] Omotosho, J.B. Balogun, A.A. and Ogunjobi, K (2000): Prediction of Monthly and Seasonal Rainfall Onset and Cessation of Rainy Season in West Africa Using only Surface Data, Int.J. Climatol., 20, 865880 .

[17] Olson, T. and Lindsay, F. (2009): Here, Today, Gone Tomorrow: Targeting Conservation Investment in the Face of Climatic Change.

[18] State Economic Empowerment and Development Strategy (SEEDS) Abridged Edition (2006)

[19] Umar Y. A (2012): Analysis of Rainfall Variability And Its Implication For Some Crops In Gombe State. Unpublished M.sc Dissertation Submitted to the Department of Geography, Bayero University Kano 